\title{
Knowledge and attitude of health care
}

\section{professionals regarding hepatitis $B$ virus infection and its vaccination, University of Gondar Hospital, Ethiopia}

\author{
Mohammed Biset Ayalew' \\ Boressa Adugna Horssa' \\ Nardose Getachew ${ }^{2}$ \\ Sitotaw Amare ${ }^{2}$ \\ Ashenafi Getnet ${ }^{2}$ \\ 'Department of Clinical Pharmacy, \\ School of Pharmacy, ${ }^{2}$ School of \\ Pharmacy, College of Medicine and \\ Health Sciences, University of Gondar, \\ Gondar, Ethiopia
}

Correspondence: Mohammed Biset Ayalew

Department of Clinical Pharmacy, School of Pharmacy, College of Medicine and Health Sciences, University of Gondar, PO Box 196, Gondar, Ethiopia

Tel +25I 93949617 I

Emailmb6767@gmail.com

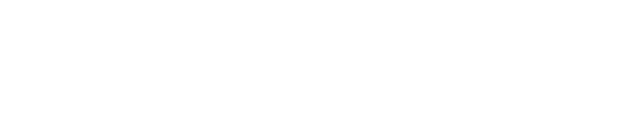

Background: Hepatitis B is a global public health problem affecting approximately $10 \%$ of the world population. Health care professionals (HCPs) are at an increased risk of acquiring hepatitis B infection due to occupational exposure. Having enough knowledge and proper attitudes toward the infection and its vaccination is crucial in preventing the infection. This study aimed to assess knowledge of and attitudes toward hepatitis B virus (HBV) infection as well as its vaccination among HCPs working in University of Gondar Hospital.

Methods: An institution-based cross-sectional study design was employed from April 1 to May 1, 2016 on 297 HCPs working at University of Gondar Hospital. A self-administered questionnaire prepared in the English language was used to collect the data. The questionnaire contained sociodemographic characteristics, knowledge, and attitude-related questions. Data were entered and analyzed using SPSS software version 20.1. Descriptive statistics, cross-tabs, and binary logistic regression were utilized. $P<0.05$ was used to declare association.

Results: From a total of 297 HCPs participated in the study $73.1 \%$ have good knowledge of HBV transmission, progress, and its vaccination. The majority $(91.3 \%)$ of the respondents believe that their job puts them at risk of HBV infection. The majority of study participants (94\%) believe vaccination is necessary. Medical doctors have 8.4 times better knowledge of HBV and its vaccination than other professionals (adjusted odds ratio $=8.399, \mathrm{CI}=1.536-45.936$ ).

Conclusion: The majority of HCPs working in University of Gondar Hospital have good knowledge of HBV transmission, progress, and its vaccination. The majority of HCPs believe that their job puts them at greater risk for HBV and vaccination is necessary. Knowledge of the HCPs significantly varies across professions.

Keywords: hepatitis B virus, knowledge, attitude, occupational exposure, health care professional

\section{Introduction}

Hepatitis B virus (HBV) is a very important public health problem affecting approximately $10 \%$ of the world population. According to a 2009 World Health Organization report, approximately 2 billion people were affected with HBV worldwide, $>350$ million suffered from chronic lifelong infection, and more than 1 million individuals die because of cirrhosis and liver cancer every year. ${ }^{1-3}$ There is high prevalence of HBV infection among Blacks. ${ }^{2}$ It is also a major public health problem in Ethiopia. ${ }^{4-8}$

Health care professionals (HCPs) are at increased risk of acquiring hepatitis B infection due to occupational exposure..$^{1,3,9}$ In one study, HCPs were shown to have up 
to a fourfold increased risk of acquiring HBV infection. ${ }^{10}$ The main risk factor to contract $\mathrm{HBV}$ infection for HCPs is direct contact with infectious material, especially HBV-infected blood or via a needle stick injury with HBV-contaminated body fluids. In particular, recapping of hollow-bore needles appears to increase the risk of needle stick injuries. An increased risk of occupational exposure affects the safety and well-being of HCPs as well as the quality of care delivered by them. HCPs in high-risk areas of hospital settings are potentially at an increased risk of experiencing substantial anxiety and depression. Hence, occupational exposure not only leads to acquiring infectious pathogens but also affect the mental health of HCPs. ${ }^{11}$ Moreover, hospital workers have low participation in vaccination, and this is especially harmful for those whose work exposes them to the risk of HBV infection. ${ }^{2}$

Another study has reported a lack of awareness of HBV among HCPs; consequently, proper precautions against blood-borne infections are lacking by these workers. ${ }^{12} \mathrm{HCPs}$ should familiarize themselves with "universal precautions", which is defined by the Center for Disease Control as an asset of precautions designed to prevent transmission of blood-borne pathogens when providing first aid or health care. Under universal precautions, blood and certain body fluids of all patients are considered potentially infectious for blood-borne pathogens such as HBV. ${ }^{13}$

A safe and effective vaccine against $\mathrm{HBV}$ has been available for approximately 20 years and is effective in preventing infection and further serious consequences of hepatitis, including liver cancer and cirrhosis, when given before or after exposure. ${ }^{3}$ It has generally been described as having an excellent safety record and is effective, with a protective efficiency of $90 \%-95 \%$. In fully vaccinated subjects, the vaccine will provide long-term protection from HBV infection, possibly even lifelong protection. ${ }^{14}$ Moreover, after exposure to blood or bodily fluids, postexposure prophylaxis can be administered as a combination of passive immunization with hepatitis B immunoglobulin and a vaccination with hepatitis $B$ vaccine. However, the most cost-effective method to prevent and control hepatitis $B$ is through preexposure vaccination and compliance of standard precautions. ${ }^{1}$

Having enough knowledge and proper attitudes toward the infection is crucial in preventing its occupational exposures. But the knowledge, attitude, and practices relating to HBV infection and its vaccination vary among HCPs. Studies have shown that the overall knowledge, attitude, and practice of HCPs about HBV infection and its vaccination is inadequate. ${ }^{15,16}$ Prevention of any disease is proportional to knowledge, attitude, and practice of the population and reflection of the importance that is paid to health-related issue by the society. ${ }^{13}$

Studies conducted to assess the knowledge and attitude of HBV and its vaccination among HCPs in Ethiopia are very rare. This study was therefore conducted to determine the level of knowledge and attitude of HBV infection and its vaccination among HCPs working in an Ethiopian teaching hospital (University of Gondar Hospital) and to identify factors affecting their knowledge of HBV infection and its vaccination.

\section{Methods}

\section{Study area and period}

The study was conducted at University of Gondar Hospital, Gondar, Ethiopia. It is $738 \mathrm{~km}$ away from the capital city of Ethiopia, Addis Ababa. The hospital has $>400$ beds and provides service in various departments including pediatrics, surgery, gynecology, psychiatry, dermatology, dentistry, ophthalmology, pharmacy, medical laboratory, and others. In the hospital, there are 943 health care workers (HCWs). The study was conducted from April 1 to May 1, 2016.

\section{Study design and subjects}

Institution-based cross-sectional study design was used to assess knowledge and attitude of HBV and its vaccination among HCPs in University of Gondar Hospital. HCPs that were not available at the workplace during the study period and those who did not want to volunteer to participate in the study were excluded. A total of 297 HCPs were included in the study. Simple random sampling technique was used to recruit study participants.

\section{Data collection and management}

Data were collected using a data collection format developed by the research authors after reviewing literature. The format consisted of sociodemographic characteristics, history of exposure to $\mathrm{HBV}$, and questions that measure knowledge and attitude of HCPs on HBV infection and its vaccination. The data collection tool was pretested on $5 \%$ of the sample population in order to check for any inconsistencies. Necessary adjustments were made accordingly before the study began. Data were collected using a structured self-administered questionnaire prepared in the English language. The data collection was done by three graduating pharmacy students after 1 day training was given. The completeness, consistency, and accuracy of the data were checked every day by the principal investigator. 


\section{Data analysis}

The collected data were processed and analyzed using SPSS version 20.1 (IBM Corporation, Armonk, NY, USA).

Descriptive statistics were calculated for the study variables and frequency distribution tables were used to describe the findings. Association between dependent and independent variables were analyzed using binary logistic regression and crude and adjusted odds ratios were calculated. $P<0.05$ was used to declare association.

\section{Ethical consideration}

This study was approved by the Ethical Review Committee of School of Pharmacy, University of Gondar. An official letter of permission was taken from the Ethical Review Committee and given to the administrative office of the hospital. Permission was taken from the responsible authorities of the hospital. The respondents were informed about the purpose of the study, and written informed consent was obtained from the study participants. Confidentiality of the information taken was assured, thus name and address of the $\mathrm{HCWs}$ were not recorded in the data collection format.

\section{Operational definition}

Good knowledge - those who answered $>60 \%$ of knowledge questions correctly.

Poor knowledge - those who answered $<60 \%$ of knowledge questions correctly.

Positive attitude - given for interviewee who answered at least $60 \%$ of attitude question positively.

Negative attitude - given for interviewee who answered $<60 \%$ of attitude question positively.

\section{Results}

\section{Sociodemographic characteristics of study subjects}

A total of 297 HCPs participated in this study. As shown in Table 1, the majority (63.6\%) were male. The age range of participants was 21-58 years with the mean age of $26.91 \pm 4.65$ years. According to their professional characteristics, majority were nurses (98 [33\%]) and medical doctors (93 [31.3\%]). Most study subjects (84.2\%) were first-degree holders. Three-fourths of participants $(75.1 \%)$ had $<5$ years of work experience.

\section{Health care professionals' knowledge on $\mathrm{HBV}$ infection and its vaccination}

Approximately three-fourths (73.1\%) of the participants have good knowledge on HBV transmission, progress, and its vaccination. The major sources of information about
Table I Sociodemographic and occupational characteristics of HCPs, University of Gondar Hospital, Gondar, Ethiopia, 2016

\begin{tabular}{|c|c|c|}
\hline Variable & Category & Frequency (\%) \\
\hline \multirow[t]{3}{*}{ Age group (years) } & $21-29$ & $246(82.8)$ \\
\hline & $30-39$ & $42(14.1)$ \\
\hline & $>40$ & $9(3)$ \\
\hline \multirow[t]{2}{*}{ Sex } & Male & $189(63.6)$ \\
\hline & Female & $108(36.4)$ \\
\hline \multirow[t]{2}{*}{ Marital status } & Single & $198(66.7)$ \\
\hline & Married & $99(33.3)$ \\
\hline \multirow[t]{4}{*}{ Religion } & Orthodox & $230(77.4)$ \\
\hline & Muslim & $28(9.4)$ \\
\hline & Protestant & $30(10.1)$ \\
\hline & Others ${ }^{\mathrm{a}}$ & $9(3.0)$ \\
\hline \multirow[t]{7}{*}{ Profession } & Medical doctor & $93(31.3)$ \\
\hline & Nurse & $98(33)$ \\
\hline & Pharmacist & $36(12.1)$ \\
\hline & Lab technologist & $26(8.8)$ \\
\hline & Midwifes & $21(7.1)$ \\
\hline & Health officer & $7(2.3)$ \\
\hline & Others $^{\mathrm{b}}$ & $16(6.0)$ \\
\hline \multirow[t]{5}{*}{ Educational level } & Certificate & $6(2.0)$ \\
\hline & Diploma & $9(3.4)$ \\
\hline & First degree & $250(84.2)$ \\
\hline & Master degree & $23(7.7)$ \\
\hline & Specialist & $9(3)$ \\
\hline Department of & Surgery & $36(12.1)$ \\
\hline \multirow[t]{8}{*}{ work } & Laboratory & $28(9.4)$ \\
\hline & Delivery unit & $30(10.1)$ \\
\hline & Emergency department & $15(5.1)$ \\
\hline & Internal medicine department & $76(25.6)$ \\
\hline & Pediatrics & $57(19.2)$ \\
\hline & Pharmacy unit & $16(5.4)$ \\
\hline & Gynecology and obstetrics & $13(4.4)$ \\
\hline & Others ${ }^{c}$ & $26(8.8)$ \\
\hline Work experience & $<5$ & $223(75.1)$ \\
\hline (years) & $\geq 5$ & $74(24.9)$ \\
\hline
\end{tabular}

Notes: 'Catholic, atheist, and Hindu; 'bealth officer, anesthesia, dentist, physiotherapies, psychiatry nurse; 'dental department, oncology, optometry, psychiatry ward, recovery, general ward.

Abbreviation: $\mathrm{HCPs}$, health care professionals.

HBV were formal education (83.5\%), followed by training $(30.6 \%)$ and internet $(17.2 \%)$. As shown in Table 2, the majority of the HCPs $(92.9 \%)$ knew that the virus can be transmitted by infected blood. However, only $72(24.2 \%)$ of them knew that urine is noninfectious. Approximately one-fifth $(21.5 \%)$ of the study subjects did not know the number of doses of the vaccine required for complete protection of HBV.

\section{Attitude of HCPs toward HBV infection and its vaccination}

As indicated in Table 3, almost all (94.6\%) of the respondents agreed or strongly agreed that $\mathrm{HBV}$ infection is a major public health problem. Respondents' attitude on whether their 
Table 2 Knowledge of HCPs on HBV transmission, progress, and vaccination in University of Gondar Hospital, Gondar, Ethiopia, 2016

\begin{tabular}{|c|c|c|}
\hline Question type & Questions & Frequency, yes (\%) \\
\hline Questions related to HBV transmission and & Can you get HBV infection through percutaneous injury? & $195(65.7)$ \\
\hline \multirow[t]{7}{*}{ prognosis } & Can you get HBV infection through mucous membrane contact with blood? & $223(75.1)$ \\
\hline & Is blood infectious body fluid? & $276(92.9)$ \\
\hline & Is vaginal fluid infectious body fluid? & $263(88.5)$ \\
\hline & Is amniotic fluid infectious body fluid? & $262(88.2)$ \\
\hline & Is urine infectious body fluid? & $225(75.8)$ \\
\hline & Is hepatitis curable disease? & $92(31.0)$ \\
\hline & Does HBV cause liver cancer? & $229(77.1)$ \\
\hline \multirow[t]{21}{*}{ Questions related to $\mathrm{HBV}$ vaccination } & How many doses of HBV vaccine required for complete protection? & \\
\hline & I dose & $3(1.01)$ \\
\hline & 2 doses & $12(4.04)$ \\
\hline & 3 doses & $233(78.5)$ \\
\hline & 6 doses & $2(0.67)$ \\
\hline & I do not know & $47(15.82)$ \\
\hline & What is the expected interval between the first dose and the next dose? & \\
\hline & I month & $174(58.58)$ \\
\hline & 2 months & $15(5.05)$ \\
\hline & 3 months & $35(11.78)$ \\
\hline & 6 months & $17(5.72)$ \\
\hline & I do not know & $56(18.8)$ \\
\hline & What is expected interval between the last dose and the dose preceding? & \\
\hline & I month & $34(11.44)$ \\
\hline & 2 months & $16(5.38)$ \\
\hline & 3 months & $35(11.78)$ \\
\hline & 6 months & $130(43.77)$ \\
\hline & I do not know & $82(27.60)$ \\
\hline & $\begin{array}{l}\text { If the vaccine is taken after exposure does it reduce the likelihood of being } \\
\text { positive for HBV? }\end{array}$ & $101(34)$ \\
\hline & $\begin{array}{l}\text { Should immunity status be checked (anti HBsAg serologic testing be done) } \\
\text { after completing the vaccine series? }\end{array}$ & $149(50.2)$ \\
\hline & $\begin{array}{l}\text { If the immunity test result is negative does the vaccine series need to be } \\
\text { repeated? }\end{array}$ & $130(43.7)$ \\
\hline
\end{tabular}

Abbreviations: $\mathrm{HBV}$, hepatitis B virus; $\mathrm{HBsAg}$, hepatitis B surface antigen; HCPs, health care professionals.

Table 3 Attitude of HCPs toward HBV infection and its vaccination, University of Gondar Hospital, Gondar, Ethiopia, 2016

\begin{tabular}{|c|c|c|c|c|c|c|}
\hline S no & Statements & $\begin{array}{l}\text { Strongly } \\
\text { agree, n (\%) }\end{array}$ & Agree, $n$ (\%) & Neutral, n (\%) & $\begin{array}{l}\text { Disagree, } \\
\text { n (\%) }\end{array}$ & $\begin{array}{l}\text { Strongly } \\
\text { disagree, } \\
\text { n (\%) }\end{array}$ \\
\hline 1 & Hepatitis is serious public health problem & $205(68.3)$ & $79(26.3)$ & $10(3.3)$ & $2(0.7)$ & $\mathrm{I}(0.3)$ \\
\hline 2 & Your job puts you at greater risk of HBV infection & $217(72.3)$ & $57(19.0)$ & $13(4.3)$ & $7(2.3)$ & $3(1)$ \\
\hline 3 & It is necessary for you to receive hepatitis B vaccine & $234(78.0)$ & $50(16)$ & $4(1.3)$ & $4(1.3)$ & $4(1.3)$ \\
\hline 4 & Hepatitis $B$ vaccine is safe & $127(42.3)$ & $100(33.3)$ & $63(21.0)$ & $6(2.0)$ & $\mathrm{I}(0.3)$ \\
\hline 5 & $\begin{array}{l}\text { After exposure to contagious fluid/material, the vaccine reduces } \\
\text { likelihood of being HBV positive }\end{array}$ & 7I (23.7) & $93(31.0)$ & $5 I(I 7.3)$ & $59(19.7)$ & $23(7.7)$ \\
\hline 6 & $\begin{array}{l}\mathrm{HBV} \text { positive } \mathrm{HCPs} \text { should not be involved in exposure prone } \\
\text { invasive procedures }\end{array}$ & $67(22.3)$ & $86(28.7)$ & $68(22.7)$ & $58(19.3)$ & $18(6.0)$ \\
\hline 7 & $\begin{array}{l}\text { The vaccine is not important if the exposure is not with patient } \\
\text { blood of known HBV positive }\end{array}$ & $32(10.7)$ & $47(15.7)$ & $39(13.0)$ & $103(34.3)$ & $76(25.3)$ \\
\hline 8 & There should be the vaccine guideline in work areas & $133(44.3)$ & $124(4 \mid .3)$ & $13(4.3)$ & $12(4.0)$ & $15(5.0)$ \\
\hline 9 & Training of the vaccine is important for a behavioral change & $160(53.3)$ & $109(36.3)$ & $16(5.3)$ & $7(2.3)$ & $5(1.7)$ \\
\hline
\end{tabular}

Abbreviations: HBV, hepatitis B virus; HCPs, health care professionals.

job puts them at greater risk of $\mathrm{HBV}$ infection seems to favor a positive response (strongly agree and agree) (91.3\%). The majority (94\%) of HCPs believe that it is necessary for them to receive a hepatitis $B$ vaccine.
Approximately half of HCPs (49.2\%) reported that they were exposed to risky conditions for HBV infection. The likely options for being exposed were listed in the survey instruments, and the respondents frequently picked being 
busy (69 [47.3\%]) and rushing at work (66 [45.2\%]). As indicated in Table 4 , the most frequently taken measure after an incidence of exposure were washing with soap, water, and antiseptic (48.6\%).

\section{Factors affecting the knowledge of HCPs on $\mathrm{HBV}$ infection and its vaccination}

A multivariate binary logistic regression analysis showed that only the type of profession has significant association with knowledge of respondents on HBV and its vaccination. As shown in Table 5, medical doctors have 8.4 times better knowledge on $\mathrm{HBV}$ and its vaccination than other professionals (adjusted odds ratio $=8.399, \mathrm{CI}=1.536-45.936$ ).

\section{Discussion}

HBV infection is a serious global public health problem. It occurs all over the world. ${ }^{1,2}$ Hepatitis B prevalence is the highest in sub-Saharan Africa and East Asia. ${ }^{17}$ Studies conducted among different segments of the population in Ethiopia also showed that HBV is a major public health problem in the country. ${ }^{717-19}$ Numerous studies have shown that HCPs are at higher risk of acquiring $\mathrm{HBV}$ than the general population. ${ }^{4,6,20,21}$ It has been estimated that approximately 6,200 HBV infections occur each year among HCPs in Sub-Saharan African., ${ }^{9,22}$ A good knowledge of HBV virus and modes of infection as well as adequate vaccination may reduce infection rate. ${ }^{2}$ This study aimed to assess the knowledge and attitude of HCPs on HBV infection and its vaccination in University of Gondar Hospital, Ethiopia.

In this study, approximately three-fourths (73.1\%) of participants had a good knowledge on HBV transmission, progress, and its vaccination. A survey conducted in Kuwait revealed that knowledge of the various aspects of $\mathrm{HBV}$ was

Table 4 Reasons for being exposed to potentially infectious situation and measures taken afterward among HCPs, University of Gondar referral and teaching hospital, Gondar, Ethiopia, 2016

\begin{tabular}{ll}
\hline Variables & Frequency (\%) \\
\hline Factors contribute to HBV exposure, N= I46 & \\
Lack of infection prevention supplies & $54(32.9)$ \\
Being busy & $69(47.3)$ \\
Rushing at work & $66(45.2)$ \\
Careless handling of the patient or & $34(23.3)$ \\
infectious material & \\
Postexposure preventive measures, N= I46 & \\
Immediately reporting & $22(15.1)$ \\
Know about patient disease & $50(34.2)$ \\
Allow injury to bleed & $3(2.1)$ \\
Wash with soap, water, and antiseptic & $71(48.6)$ \\
\hline
\end{tabular}

Note: The total percentage may excide 100 because participants may choose more than one alternative.

Abbreviations: $\mathrm{HBV}$, hepatitis B virus; $\mathrm{HCPs}$, health care professionals. generally high. ${ }^{23}$ In a study conducted at Bahir Dar, Ethiopia, more than half (52\%) of the respondents were knowledgeable about hepatitis B infection, and $62 \%$ of HCWs were knowledgeable about the hepatitis B vaccine. ${ }^{1}$ In contrast to our finding, the knowledge of HBV is generally low among the populace in a study carried out among Turkish community in the Netherlands. ${ }^{24}$ This may be because HCPs have better access to health-related information than non health care professionals.

The majority of the participants $(92.9 \%)$ knew that the virus can be transmitted by infected blood. Approximately $88 \%$ of the study subjects knew that vaginal and amniotic fluids can transmit the virus. Similarly, studies carried out among HCPs in Sudan and Morocco revealed that most had a good knowledge of blood as a medium of infection. ${ }^{25,26}$ According to a study done among operating room personnel in Nigeria, the majority of HCPs had a good knowledge on the risk factors for $\mathrm{HBV}$ infection. More than $80 \%$ of them believed that HBV infection can be transmitted through percutaneous injury, mucous membrane contact with blood, and contact of abraded skin with potentially infected tissue..$^{27}$ In a cross-sectional study carried out in four public hospitals in Wad Meden, Sudan, a good respondents' knowledge about HBV transmission was observed. A study conducted in Addis Ababa, Ethiopia also showed that HCPs' knowledge regarding occupational transmission of $\mathrm{HBV}$ was good (Gashu, unpublished data, 2015).

Almost all (94.6\%) of the respondents agreed or strongly agreed that HBV infection is a great public health problem. Respondents' attitude on whether their job puts them at greater risk of HBV infection seems to favor positive response (strongly agree and agree) $(91.3 \%)$. The majority of the study participants (94\%) believe vaccination is necessary. A survey conducted in Kuwait revealed a similar finding indicating $80.5 \%$ of respondents believed that their job put them at risk of HBV infection, and $86.3 \%$ considered that it was necessary to receive the vaccine. ${ }^{23}$ In the study conducted at Bahir Dar, Ethiopia, $64.7 \%$ of respondents perceived their risk of acquiring hepatitis $B$ infection was high or very high. ${ }^{1}$

Approximately half (49.2\%) of study participants have been exposed to risky conditions for HBV infection. The most frequently picked likely options for being exposed were being busy (47.3\%) and rushing at work (45.2\%). The study conducted in Addis Ababa, Ethiopia also indicated being busy as the primary contributory factor for exposure. The most frequently taken measures after the incidence of the exposure were washing with soap, water, and antiseptic (48.6\%). The Center for Disease Control recommends all 
Table 5 Determinants of knowledge status about HBV infection and its vaccination among HCPs working in University of Gondar Hospital, Gondar, Ethiopia, 2016

\begin{tabular}{|c|c|c|c|c|c|}
\hline \multirow[t]{2}{*}{ Variable } & \multirow[t]{2}{*}{ Category } & \multicolumn{2}{|c|}{ Knowledge status } & \multirow[t]{2}{*}{ COR (95\%) } & \multirow[t]{2}{*}{ AOR (95\%) } \\
\hline & & Good, n (\%) & Poor, n (\%) & & \\
\hline \multirow[t]{3}{*}{ Age group (years) } & $20-29$ & I8I (83.4) & $65(81.2)$ & $1.392(0.338-5.729)$ & $1.565(0.260-9.324)$ \\
\hline & $30-39$ & $30(13.8)$ & $12(15.0)$ & $1.250(0.268-5.826)$ & $2.007(0.316-12.744)$ \\
\hline & $>40$ & $6(2.8)$ & $3(3.8)$ & 1.000 & 1.000 \\
\hline \multirow[t]{2}{*}{ Sex } & Male & I44 (66.4) & $45(56.2)$ & 1.534 (0.909-2.59I) & $0.946(0.469-1.909)$ \\
\hline & Female & $73(33.6)$ & $35(43.8)$ & I & 1.000 \\
\hline \multirow[t]{2}{*}{ Marital status } & Unmarried & $159(73.3)$ & $39(48.8)$ & $2.882(0.694-4.904)$ & $2.634(0.265-5.487)$ \\
\hline & Married & $58(26.7)$ & $4 \mid(5 I .2)$ & 1.000 & 1.000 \\
\hline \multirow[t]{4}{*}{ Religion } & Orthodox & 169 (77.9) & $61(76.2)$ & $2.216(0.576-8.524)$ & $2.289(0.4 \mid 7-12.556)$ \\
\hline & Muslim & $16(7.4)$ & $12(15.0)$ & $1.067(0.235-4.843)$ & $1.617(0.244-10.728)$ \\
\hline & Protestant & $27(12.4)$ & $3(3.8)$ & $7.200(0.220-42.492)$ & $6.096(0.719-51.670)$ \\
\hline & Others & $5(2.3)$ & $4(5.0)$ & 1.000 & 1.000 \\
\hline \multirow[t]{7}{*}{ Profession } & Medical doctor & $86(39.6)$ & $7(8.8)$ & $9.556(2.73|-| 33.440)$ & $8.399(1.536-45.936)$ \\
\hline & Nurse & $66(30.4)$ & $32(40.0)$ & $1.604(0.548-4.696)$ & $2.546(0.574-11.301)$ \\
\hline & Health officer & $6(2.8)$ & I (I.2) & $4.667(0.45 I-48.257)$ & $4.370(0.310-61.695)$ \\
\hline & Pharmacist & $19(8.8)$ & I7 (2I.I) & $0.869(1.266-2.843)$ & $1.843(0.323-10.499)$ \\
\hline & Laboratory technologist & $20(9.2)$ & $6(7.5)$ & $2.593(0.676-9.947)$ & $23.429(0.664-827.226)$ \\
\hline & Midwives & II (5.I) & $10(12.5)$ & $0.856(0.23 I-3.162)$ & $0.928(0.152-5.663)$ \\
\hline & Others & $9(4.1)$ & $7(8.8)$ & 1.000 & 1.000 \\
\hline \multirow[t]{5}{*}{ Education level } & Certificate & $5(2.3)$ & I (I.2) & $0.625(0.03|I-12.4| 0)$ & $0.574(0.013-26.230$ \\
\hline & Diploma & $3(1.4)$ & $6(7.5)$ & $0.063(0.005-0.760)$ & $0.072(0.002-2.103)$ \\
\hline & First degree & $183(84.3)$ & $67(83.3)$ & $0.34 I(0.042-2.78 I)$ & $0.337(0.017-6.577)$ \\
\hline & Master's degree & $18(8.3)$ & $5(6.2)$ & $0.450(0.045-4.501)$ & $0.337(0.017-6.577)$ \\
\hline & Specialist & $8(3.7)$ & I (I.2) & 1.000 & 1.000 \\
\hline \multirow[t]{9}{*}{ Department of working } & Surgery & $30(13.8)$ & $6(7.5)$ & $3.667(1.136-11.838)$ & $1.979(0.457-8.569)$ \\
\hline & Laboratory & $21(9.7)$ & $7(8.8)$ & $2.200(0.692-6.992)$ & $0.212(0.008-5.431)$ \\
\hline & Delivery unit & $23(10.6)$ & $7(8.8)$ & $2.410(0.763-7.605)$ & 3.841 (0.769-19.174) \\
\hline & Emergency department & $8(3.7)$ & $7(8.8)$ & $0.838(0.233-3.009)$ & $0.657(0.128-3.390)$ \\
\hline & Internal medicine & $57(26.3)$ & $19(23.8)$ & $2.200(0.863-5.606)$ & $0.990(0.286-3.424)$ \\
\hline & Pediatrics & $45(20.7)$ & $12(15.0)$ & $2.750(1.006-7.516)$ & $\mathrm{I} .007(0.262-3.878)$ \\
\hline & Pharmacy unit & $9(4.1)$ & $7(8.8)$ & $0.943(0.268-3.315)$ & $1.196(0.211-6.767)$ \\
\hline & Gynecology and obstetrics & $9(4.1)$ & $4(5.0)$ & $1.650(0.402-6.769)$ & $0.936(0.15 I-5.790)$ \\
\hline & Others & $15(6.9)$ & II (I3.8) & 1.000 & 1.000 \\
\hline \multirow[t]{2}{*}{ Work experience (years) } & $<5$ & $165(76.0)$ & $58(72.5)$ & I.204 (0.673-2.I53) & $0.721(0.316-1.642)$ \\
\hline & $>5$ & $52(24.0)$ & $22(27.5)$ & 1.000 & 1.000 \\
\hline \multirow[t]{2}{*}{ Attend training } & Yes & I54 (7I.0) & $36(45.0)$ & 2.988 (I.760-5.07I) & I.786 (0.903-3.535) \\
\hline & No & $63(29.0)$ & $44(55.0)$ & 1.000 & 1.000 \\
\hline
\end{tabular}

Abbreviations: HBV, hepatitis B virus; HCPs, health care professionals; COR, crude odds ratio; AOR, adjusted odds ratio.

HCPs to immediately make a report after encountering an injury. But according to our finding, immediate reporting after exposure to risky conditions for HBV infection was practiced only in $7.3 \%$ of the respondents.

In this study, $77.7 \%$ of the study subjects correctly answered the number of doses of the vaccine required for complete protection of HBV. A closer result was found in the study conducted at Addis Ababa, Ethiopia (Gashu, unpublished data, 2015). Accordingly, 75.2\% of the study subjects correctly answered the number of doses of the vaccine required for complete protection of $\mathrm{HBV}$ infection.

In this study, only the type of profession was found to have a significant association with the knowledge status of HCPs on HBV and its vaccination. Similarly, the study conducted in Addis Ababa showed that the type of profession has significant association with the knowledge status of HCPs on HBV and its vaccination. A study conducted in Nigeria also indicated that there was no significant association between good knowledge of HBV infection and any sociodemographic variables. ${ }^{9}$

Since half of HCPs believed that they have been exposured to risky conditions, hospital administrators and policy makers need to consider expanding the currently available prevention facilities and put in place sustainable infection control and prevention strategies. Training HCWs on safe handling and proper disposal of potentially infectious fluids and devices is important to reduce occupational hepatitis B transmission. As the knowledge level of HCPs is not sufficient (73.1\%), it 
would be very helpful if awareness creation activities such as disseminating important information on $\mathrm{HBV}$ infection and its vaccination were done.

\section{Conclusion}

HCPs working in University of Gondar Hospital have a good knowledge on HBV transmission, progress, and its vaccination. The majority of HCPs believe that their job puts them at a greater risk for HBV and a vaccination is necessary. The main reasons for HCPs being exposed to were being busy and rushing at work. HCPs' knowledge significantly varies across professions.

\section{Acknowledgments}

Our appreciation goes to the School of Pharmacy of University of Gondar for providing us essential materials used in conducting the study. We would also like to thank study participants for their time in completing the questionnaire.

\section{Disclosure}

The authors report no conflicts of interest in this work.

\section{References}

1. Abeje G, Azage M. Hepatitis B vaccine knowledge and vaccination status among health care workers of Bahir Dar City Administration, Northwest Ethiopia: a cross sectional study. BMC Infect Dis. 2015;15:30.

2. Adekanle O, Ndububa DA, Olowookere SA, Ijarotimi O, Ijadunola KT. Knowledge of Hepatitis B virus infection, immunization with hepatitis $B$ vaccine, risk perception, and challenges to control hepatitis among hospital workers in a Nigerian Tertiary Hospital. Hep Res Treat. 2015;2015:1-6.

3. Hamissi J, Tabari ZA, Najafi K, Hamissi H, Hamissi Z. Knowledge, attitudes and practice of hepatitis $B$ vaccination among Iranian dentists. Int J Collab Res Intern Med Public Health. 2014;6:199-206.

4. Shiferaw Y,Abebe T, Mihre A. Hepatitis B virus infection among medical waste handlers in Addis Ababa, Ethiopia. BMC Res Notes. 2011;4:479.

5. Anagaw B, Shiferaw Y, Anagaw B, et al. Seroprevalence of hepatitis $\mathrm{B}$ and $\mathrm{C}$ viruses among medical waste handlers at Gondar town health institutions, Northwest Ethiopia. BMC Res Notes. 2012;5:55.

6. Geberemicheal A, Gelaw A, Moges F, Dagnew M. Seroprevalence of hepatitis B virus infections among health care workers at the Bulle Hora Woreda Governmental Health Institutions Southern Oromia, Ethiopia. J Environ Occup Sci. 2013;2(1):9-14.

7. Abebe A, Nokes D, Nejene A, Enquselassie F, Messele F, Cutts F. Seroepidemiology of hepatitis B virus in Addis Ababa Ethiopia: transmission patterns and vaccine control. Epidemiol Infect. 2003;131(1):757-70.

8. Negero A, Sisay Z, Medhin G. Prevalence of hepatitis B surface antigen (HBsAg) among visitors of Shashemene General Hospital voluntary counselling and testing center. BMC Res Notes. 2011;4(35):1-5.

9. Hassan M, Awosan KJ, Nasir S, Tunau K, Burodo A, Yakubu A, Oche MO. Knowledge, risk perception and hepatitis $B$ vaccination status of healthcare workers in Usmanu Danfodiyo University Teaching Hospital, Sokoto, Nigeria. J Public Health Epidemiol. 2016;8(4):53-59.
10. Ciorlia LA, Zanetta DM. Hepatitis B in healthcare workers: prevalence, vaccination and relation to occupational factors. Braz J Infect Dis. 2005;9(5):384-389.

11. Sohn JW, Kim BG, Kim SH, Han C. Mental health of healthcare workers who experience needlestick and sharps injuries. J Occup Health. 2006;48(6):474-479.

12. Sukriti BA, Pati NT, Sethi A, Agrawal K, Kumar GT. Low levels of awareness, vaccine coverage, and the need for boosters among health care workers in tertiary care hospitals in India. J Gastroenterol Hepatol. 2008;23(11):1710-1715.

13. Mesfin YM, Kibret KT. Assessment of knowledge and practice towards hepatitis B among medical and health science students in Haramaya University, Ethiopia. PLoS One. 2013;8(11):1-6.

14. Weinbaum CM, Mast EE, Ward JW. Recommendations for identification and public health management of persons with chronic hepatitis B virus infection. Hepatology. 2009;49(5 Suppl):S35-S44.

15. Habib F, Khan DK, Shan EA, Bhatti F, Zafar A. Knowledge and beliefs among health care workers regarding hepatitis B infection and needle stick injuries at a tertiary care hospital, karachi. J Coll Physicians Surg Pak. 2011;21(5):317-318.

16. Laraqui O, Laraqui S, Tripodi D, et al. Evaluation of knowledge, attitudes and practices in the health care setting in Morocco with regard to hepatitis B and C. Sante Publique. 2009;21(3):271-286.

17. WHO, Hepatitis B fact sheet. [Updated July 2016]. Available from: http://www.who.int/mediacentre/factsheets/fs204/en/. Accessed July 5, 2016.

18. Yami A, Alemseged F, Hassen A. Hepatitis B and C viruses infections and their association with human immunodeficiency virus: a crosssectional study among blood donors in Ethiopia. Ethiop J Health Sci. 2011;21(1):67-75.

19. Shimelis T, Torben W, Medhin G, et al. Hepatitis B virus infection among people attending the voluntary counselling and testing center and anti retroviral therapy clinic of St Paul's General Specialized Hospital Addis Ababa, Ethiopia. Sex Transm Infect. 2008;84(1):37-41.

20. Sepkowitz KA. Occupationally acquired infections in health care workers, Part II. Ann Intern Med. 1996;125(11):917-928.

21. Beltrami EM, Williams IT, Shapiro CN, Chamberland ME. Risk and management of blood-borne infections in HCWs. Clin Microbiol Rev. 2000;13(3):385-407.

22. Pruss-Ustun A, Rapiti E, Hutin Y. Estimation of the global burden of disease attributable to contaminated sharps injuries among health-care workers. Am J Ind Med. 2005;48(6):482-490.

23. Soad A, Ghadeer A, Afaf EM, Ghizayel RA, Gamal M, Medhat KE. Knowledge, attitude and behavior of health care workers regarding hepatitis B infection in primary health care, Kuwait. GJMS. 2012;2(4): 77-83.

24. VanDerVeen Y, Voeten H, Zwart O, Richardus J. Awareness, knowledge and self-reported test rates regarding Hepatitis B in Turkish-Dutch: a survey. BMC Public Health. 2010;10:512.

25. Bakry SH, Mustafa AF, Eldalo AS, Yousif MA. Knowledge, attitude and practice of health care workers toward hepatitis B virus infection, Sudan. Int J Risk Saf Med. 2012;24(2):95-102.

26. Djeriri K, Laurichesse H, Merle J, et al. Hepatitis B in Moroccan health care workers. Occup Med (Lond). 2008; 58(6):419-424.

27. Emeka B, Kenechi U, Eshiobo I, Dongo A, Bwala KJ, Alegbeleye BJ. Knowledge of hepatitis B vaccine among operating room personnel in Nigeria and their vaccination status. Hepat Res Treat. 2011;2011:157089. Article ID157089.

28. CDC. Updated U.S. public health service guidelines for the management of occupational exposures to HBV, HCV, and HIV and recommendations for postexposure prophylaxis [Updated September 25, 2013]. Available from: https://stacks.cdc.gov/view/cdc/20711. Accessed July, 2016. 


\section{Publish your work in this journal}

Hepatic Medicine: Evidence and Research is an international, peerreviewed, open access journal covering all aspects of adult and pediatric hepatology in the clinic and laboratory including the following topics: Pathology, pathophysiology of hepatic disease; Investigation and treatment of hepatic disease; Pharmacology of drugs used for the treatment

of hepatic disease. Issues of patient safety and quality of care will also be considered. The manuscript management system is completely online and includes a very quick and fair peer-review system, which is all easy to use. Visit http://www.dovepress.com/testimonials.php to read real quotes from published authors.

Submit your manuscript here: https://www.dovepress.com/hepatic-medicine-evidence-and-research-journal 